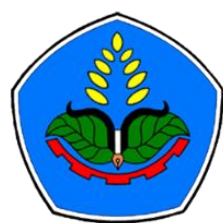

AGROPROSS

National Conference

Proceedings of Agriculture
Proceedings:

Peran Teaching Factory di Perguruan Tinggi Vokasi Dalam Mendukung Ketahanan Pangan Pada Era New Normal

Tempat : Politeknik Negeri Jember

Tanggal : 8-9 Juli 2020

Publisher :

Agropross, National Conference Proceedings of Agriculture

ISBN : 978-623-94036-6-9

DOI : 10.25047 /agropross.2020.46

\title{
Aplikasi Asam Humat Terhadap Pertumbuhan dan Produksi Tanaman Jagung Manis (Zea mays saccharata Sturt.)
}

\author{
Author(s): Nadia Putri Lestari ${ }^{(1)}$, M. Zayin Sukri ${ }^{(1) *}$ \\ (1) Program Studi Produksi Tanaman Hortikultura, Jurusan Produksi Pertanian, Politeknik Negeri Jember \\ * Corresponding author: m_zayin@polije.ac.id
}

\begin{abstract}
The aim of the study to determine the response of application of humid acid on the growth and production of sweet corn cultivation and also to determine the feasibility of farming corn plants. The experiment was conducted at State Polytechnic of Jember in experimental fields with a height of 89 meters above sea levels begining in June until September 2019. This study was use a preexperimental design through a static group comparison approach with t-test analysist and farm expantion analysist. The parameters observed reveal: plant height, number of leaves, cobs diameter, cobs length, cobs weight, ingratiating level and total cobs weight. The result was shown that the application of humic acid at a dose $20 \mathrm{~kg} / \mathrm{ha}$ was given had significantly affected plant height at the age of 28 HST, 35 HST and 42 HST, the number of leaves was 14 HST, 35 HST and 42 HST, cobs weight and cobs length. The application of humic acid is also significantly affected the parameters of cobs diameter, ingratiating levels and to get sweet corn production of 15 tons/ha with an R/C Ratio of 1,46. To get obtaining optimal growth and production of sweet corn cultivation was given with higher doses of humic acid.
\end{abstract} Keywords:

Humic acid;

Sweet corn;

Farm expantion

\section{Kata Kunci: \\ Asam humat; \\ Jagung manis; \\ Usaha tani;}

\begin{abstract}
ABSTRAK
Penelitian ini bertujuan untuk mengetahui pengaruh penggunaan asam humat terhadap pertumbuhan dan produksi tanaman jagung manis serta mengetahui kelayakan usahatani budidaya tanaman jagung manis. Penelitian dilaksanakan dilahan percobaan kampus Politeknik Negeri Jember pada bulan Juni-September 2019 dengan ketinggian tempat 89 mdpl. Penelitian ini menggunakan rancangan praeksperimen melalui pendekatan static group comparison dengan analisis $t$ test dan analisis usahatani. Parameter yang diamati yaitu: tinggi tanaman, jumlah daun, diameter tongkol, panjang tongkol, berat tongkol, tingkat kemanisan dan total berat tongkol. Hasil penelitian menunjukkan pelakuan asam humat dengan dosis $20 \mathrm{~kg} / \mathrm{ha}$ berpengaruh sangat nyata terhadap tinggi tanaman pada umur 28 HST, 35 HST, dan 42 HST, jumlah daun 14 HST, 35 HST dan 42 HST, berat tongkol dan panjang tongkol. Aplikasi asam humat juga berpengaruh nyata terhadap parameter diameter tongkol dan tingkat kemanisan serta menghasilkan produksi jagung manis sebesar 15 ton/ha dengan nilai R/C Ratio 1,46. Untuk mendapatkan pertumbuhan dan produksi tanaman jagung manis yang lebih optimal disarankan melakukan budidaya jagung manis dengan dosis asam humat yang lebih tinggi
\end{abstract}




\section{PENDAHULUAN}

Jagung manis merupakan komoditas hortikultura yang tergolong dalam sayuran buah yang banyak digemari oleh masyarakat karena cita rasanya yang manis, kaya akan vitamin, protein, rendah lemak dan karbohidrat yang cocok digunakan sebagai pelengkap makanan (Sari dkk., 2016). Didalam jagung manis (sweet corn) kadar gulanya relatif tinggi dibandingkan dengan kadar gula jagung biasa, sehingga memberikan rasa manis yang disukai oleh masyarakat Indonesia dan dapat langsung dikonsumsi secara segar maupun di jadikan jagung bakar (Sirajuddin dan Lasmini, 2010).

Berdasarkan data Statistik

Pertanian produksi jagung di Indonesia dari tahun 2014-2018 terus mengalami peningkatan dari 19.008 ton/ha menjadi 30.056 ton/ha. Peningkatakan produksi jagung diikuti dengan peningkatan luas panen sebesar 3,64\% yaitu sekitar 5.734 ha (Kementrian Pertanian, 2018). Menurut Syafruddin dkk (2012), tanaman jagung manis sangat respon terhadap tanah dengan kesuburan tinggi. Untuk menambah tingkat kesuburan tanah agar mendapatkan produksi jagung manis yang meningkat diupayakan dengan menerapkan budidaya dengan memperhatikan kondisi tanahnya, berupa pengaplikasian bahan organik sebagai pembenah tanah salah satunya adalah asam humat.

Asam humat merupakan senyawa yang berwarna gelap (coklat kehitaman) dengan tekstur gembur yang merupakan hasil perombakan mikroorganisme tanah dari sisa-sisa makhluk hidup berupa hewan maupun tanaman, dimana asam humat memiliki kemampuan untuk menurunkan kadar kelarutan $\mathrm{Fe} 2+$ dalam tanah. Semakin sedikit kadar $\mathrm{Fe} 2+$, maka daya serap unsur hara $\mathrm{P}$ oleh tanaman semakin meningkat (Dani, 2018). Dengan meningkatnya status kesuburan tanah, sehingga diharapkan serapan hara tanaman akan meningkat. Menurut Firda dkk
(2016), didalam asam humat terkandung unsur $\mathrm{C}$ sebesar $40-80 \%$, unsur $\mathrm{N}$ sebesar 2-4\%, unsur $\mathrm{S}$ sebesar 1-2\%, dan unsur $\mathrm{P}$ sebesar $0-0,3 \%$. Berdasarkan penelitian Hermanto dkk. (2013) penggunaan asam humat sebagai pelengkap pupuk dengan dosis $20 \mathrm{~kg} / \mathrm{ha}$ menunjukkan respon peningkatan pertumbuhan tanaman yang didukung dengan peningkatan ketersediaan hara dan pengambilan unsur hara tertinggi dibandingkan dengan dosis yang lain. Hasil penelitian Suwardi dkk., (2009) menjelaskan bahwa aplikasi asam humat yang diberikan kedalam tanah mampu meningkatkan hasil padi sebanyak $15 \%$ dan hasil jagung sebanyak $10 \%$ dengan dosis 10 liter/ha. Tujuan di lakukannya penelitian ini adalah untuk mengetahui pengaruh asam humat terhadap pertumbuhan dan produksi tanaman jagung manis dan untuk mengetahui kelayakan usahatani budidaya tanaman jagung manis.

\section{BAHAN DAN METODE Tempat dan Waktu Kegiatan}

Kegiatan ini dilaksanakan pada bulan Juni sampai September 2019 di lahan Blok O Politeknik Negeri Jember dengan ketinggian $89 \mathrm{mdpl}$.

\section{Metode Penelitian}

Metode statistik yang di gunakan dalam kegiatan ini adalah dua kelompok subyek (kelompok perlakuan dan kelompok kontrol). Luasan yang digunakan dalam penelitian seluas $240 \mathrm{~m}^{2}$, selanjutnya lahan dibagi menjadi 2 dengan luasan $120 \mathrm{~m}^{2}$. Lahan pertama dengan aplikasi asam humat, sedangkan lahan kedua tanpa aplikasi asam humat (kontrol). Aplikasi asam humat sebanyak $20 \mathrm{~kg} / \mathrm{ha}$ dengan cara dikocor pada tanaman jagung manis pada hari ke 15 HST dan 30 HST.Populasi tanaman dalam luasan 240 $\mathrm{m}^{2}$ sebanyak 1.600 tanaman, sampel yang diamati setiap luasan sebanyak 30 tanaman. Masing-masing perlakuan dianalisis menggunakan $t$-test dan analisis kelayakan usahatani. 


\section{Bahan dan Alat}

Bahan yang digunakan adalah benih jagung manis varietas F1 Talenta, asam humat, pupuk kandang sapi, pupuk Urea, pupuk SP-36, pupuk $\mathrm{KCl}$, Insure max, Furadan, Ridomil Gold, Confidor, dan Gandewa. Alat yang digunakan adalah cangkul, gembor, koret, meteran, sabit, kenco, knapsack, tugal, jangka sorong, timbangan analitik, refraktometer, kamera dan ATK.

\section{Parameter Pengamatan}

Parameter pengamatan yang di gunakan pada penelitian ini adalah :

a. Tinggi Tanaman $(\mathrm{cm})$

Mengamati tinggi tanaman jagung manis mulai dari pangkal bawah hingga titik tumbuh, pengamatan di lakukan 1 minggu sekali.

b. Jumlah Daun (helai)

Mengamati jumlah daun tanaman jagung manis yang telah tumbuh sempurna, di lakukan 1 minggu sekali dari helai daun pertama setelah helai daun termuda yang sudah terbentuk.

c. Diameter Tongkol $(\mathrm{cm})$

Mengamati diameter tongkol jagung manis pada pengamatan terakhir yaitu hari ke 75 setelah tanam dengan menggunakan jangka sorong pada tongkol bagian tengah.

d. Panjang Tongkol $(\mathrm{cm})$

Mengamati panjang tongkol jagung manis pada pengamatan terakhir yaitu hari ke 75 setelah tanam dengan menggunakan penggaris pada pangkal tongkol hingga bagian ujung.

e. Bobot Tongkol (gram)

Menghitung bobot tongkol masing masing sampel, di hitung pada pengamatan terakhir yaitu hari ke 75 setelah tanam dengan menggunakan timbangan analitik.

f. Tingkat Kemanisan (brix)

Mengukur tingkat kemanisan jagung manis pada pengamatan terakhir yaitu hari ke 75 setelah tanam dengan menggunakan alat hand refraktometer. g. Kelayakan usahatani

Menghitung bobot tongkol per luasan $240 \mathrm{~m}^{2}$, di hitung pada pengamatan terakhir yaitu hari ke 75 setelah tanam dengan menggunakan timbangan dan kemudian dianalisa menggunakan analisis kelayakan usahatani.

\section{HASIL DAN PEMBAHASAN Tinggi Tanaman}

Berdasarkan gambar 1 di atas, terlihat bahwa pertumbuhan tinggi tanaman dengan perlakuan asam humat memberikan respon berbeda nyata pada hari ke 28 setelah tanam. Pertumbuhan tinggi pada tanaman jagung manis disebabkan oleh pemberian asam humat yang mampu meningkatkan $\mathrm{N}$-total serta berperan penting dalam pertumbuhan vegetatif terutama dalam memperbesar dan mempertinggi tanaman, selain $\mathrm{N}$-total asam humat juga mampu meningkatkan $\mathrm{C}$ Organik, dan P-tersedia dalam tanah yang dibutuhkan tanaman dalam proses metabolisme enzim maupun penyusunan jaringan (Ihdaryanti, 2011).

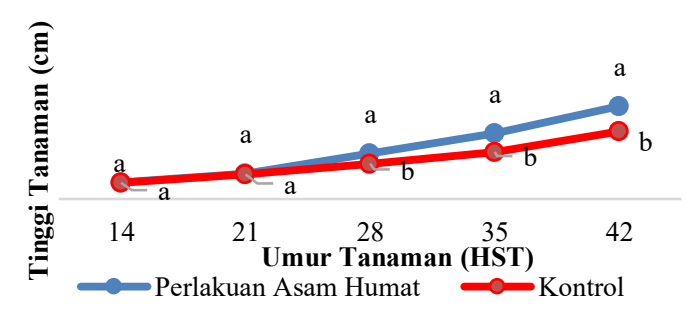

Gambar 1. Hasil Pengamatan Tinggi Tanaman

Keterangan : Nilai rerata antar perlakuan yang diikuti dengan huruf sama pada pengamatan menunjukkan tidak berbeda nyata pada uji-t taraf $5 \%$.

Asam humat secara fisik mampu menyelimuti pupuk nitrogen sehingga mampu menghambat proses penguapan pupuk menjadi gas amoniak, di samping itu asam humat mengandung zat perangsang tumbuh yang mampu merangsang pertumbuhan akar menjadi lebih baik serta dengan adanya mekanisme pengikatan ion 
ammonium diharapkan dapat menghambat penguapan nitrogen dan merangsang perkembangan akar sehingga dapat meningkatkan pertumbuhan tanaman (Suwardi, 2009).

\section{Jumlah Daun}

Berdasarkan hasil pengamatan di atas penambahan jumlah daun memberikan respon pada hari ke 28 setelah tanam. Asam humat mengandung unsur hara Fosfor, Kalium, Kalsium, Besi, Mangan, dan Seng (Tahir et al., 2011) serta zat pemicu pertumbuhan tanaman berupa asam amino, vitamin, auksin, dan Indole Acetic Acid (IAA) (Ihdaryanti, 2011). Auksin memiliki peran sebagai permeabilitas dinding sel dalam peningkatan serapan unsur hara $\mathrm{N}, \mathrm{Mg}, \mathrm{Fe}$, dan $\mathrm{Cu}$ yang dibutuhkan saat pembentukan klorofil dalam proses fotosintesis. Ferara dan Brunetti (2010), menyatakan bahwa peningkatan kandungan klorofil pada daun disebabkan oleh adanya peningkatan proses metabolisme berupa fotosintesis pada tanaman.

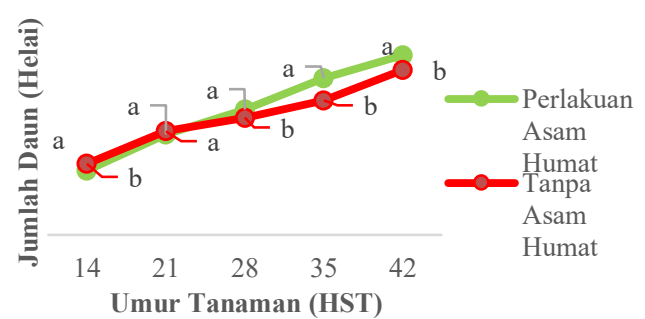

Gambar 2. Hasil Pengamatan Jumlah Daun Keterangan : Nilai rerata antar perlakuan yang diikuti dengan huruf sama pada pengamatan menunjukkan tidak berbeda nyata pada uji-t taraf $5 \%$.

Pertumbuhan tanaman sangat dipengaruhi oleh faktor gen dan lingkungan salah satunya adalah ketersediaan hara. Menurut Syafruddin et al (2012), bahwa ketersediaan hara Nitrogen, Fosfor, dan Kalium di dalam tanah pada budidaya jagung manis mampu meningkatkan pertumbuhan organ tanaman yaitu daun. Daun merupakan tempat berlangsungnya proses fotosintesis.
Semakin banyak jumlah daun, luas daun akan semakin meningkat, maka proses fotosintesis pun akan semakin meningkat.

\section{Diameter Tongkol}

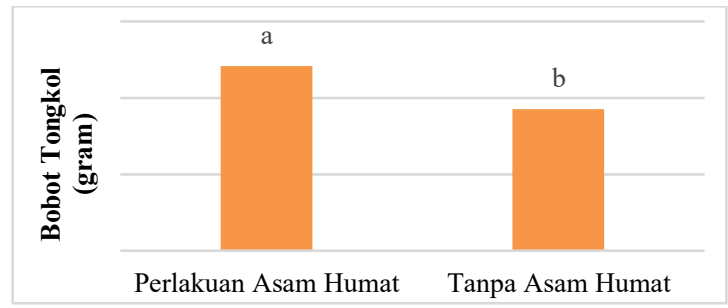

Gambar 3. Rata-rata diameter tongkol

Keterangan : Nilai rerata antar perlakuan yang diikuti dengan huruf sama pada pengamatan menunjukkan tidak berbeda nyata pada uji-t taraf 5\%.

Besar kecilnya diameter tongkol dapat di pengaruhi oleh berbagai hal, di antaranya keunggulan varietas, kemampuan adaptasi, kemampuan menyerap unsur hara, dan lain sebagainya. Pembesaran diameter tongkol sangat dipengaruhi oleh unsur hara Kalium. Hermanto dkk (2003), menjelaskan bahwa didalam asam humat mengandung unsur hara Kalium. Diduga aplikasi pupuk $\mathrm{KCl}$ dengan dosis $100 \mathrm{~kg} / \mathrm{ha}$ mampu meningkatkan pembesaran tongkol hal ini selaras dengan pernyataan Mutaqin dkk (2019), bahwa dosis $150 \mathrm{~kg} / \mathrm{ha}$ pupuk $\mathrm{KCl}$ berpengaruh sangat nyata terhadap bobot tongkol tanpa kelobot, panjang tongkol, diameter tongkol, dan jumlah baris biji. Dengan meningkatnya dosis Kalium maka ukuran diameter tongkol jagung manis pun semakin meningkat. Kalium merupakan unsur hara makro yang diserap oleh tanaman dalam jumlah besar dalam bentuk $\mathrm{K}^{+}$, sehingga apabila kalium dalam tanah tidak tercukupi maka akan mempengaruhi proses metabolisme karbohidrat serta aktivator berbagai macam enzim. 


\section{Panjang Tongkol}

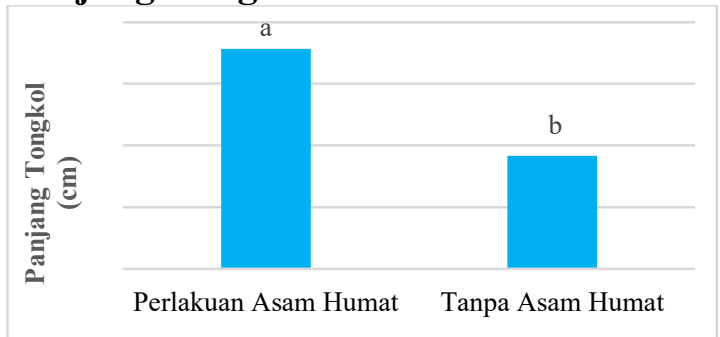

Gambar 4. Rata-rata panjang tongkol

Keterangan : Nilai rerata antar perlakuan yang diikuti dengan huruf sama pada pengamatan menunjukkan tidak berbeda nyata pada uji-t taraf $5 \%$.

Hasil t-test menunjukkan bahwa pelakuan asam humat berpengaruh nyata terhadap panjag tongkol. Berdasarkan Gambar 4 dapat diketahui bahwa perlakuan asam humat $20 \mathrm{~kg} / \mathrm{ha}$ menghasilkan panjang tongkol sebesar 20,57 cm. Tongkol terbentuk dari bunga betina. Unsur hara Fosfor sangat berperan dalam pembentukan bunga dan ukuran tongkol sedangkan unsur hara Kalium berperan dalam pembentukan panjang tongkol, diameter tongkol dan bobot tongkol (Mutaqin dkk, 2019). Asam humat merupakan senyawa organik yang berasal dari dekomposisi bahan organik yang mampu larut dalam konsdisi basa dan mengendap dalam kondisi asam yang banyak dijumpai dalam bahan organik tanah, kompos, dan batu bara muda (Ihdaryanti, 2011). Secara tidak langsung asam humat berpengaruh dalam memperbaiki sifat fisik, kima maupun biologi tanah. Hermanto, dkk (2013), menjelaskan asam humat mampu menyediakan unsur hara N,P,K,S serta karbon sebagai sumber energi bagi mikrobia tanah.

Senyawa organik mampu menyediakan energi dan mineral yang merupakan syarat tumbuh untuk mikroorganisme di dalam tanah. Energi yang tersimpan berfungsi untuk berbagai macam reaksi metabolisme organisme yang menguntungkan sehingga mampu mempengaruhi kesuburan tanah dan kesehatan tanaman. (Pettit, 2008). Dengan meningkatnya kesuburan tanah dan kesehatan tanaman khususnya perakaran mampu mengoptimalkan penyerapan unsur hara dan mineral didalam tanah yang diperlukan dalam proses fotosintesis, sehingga hasil fotosintesis yang berupa karbohidrat dapat ditranslokasikan kebagian tongkol.

\section{Bobot Tongkol}

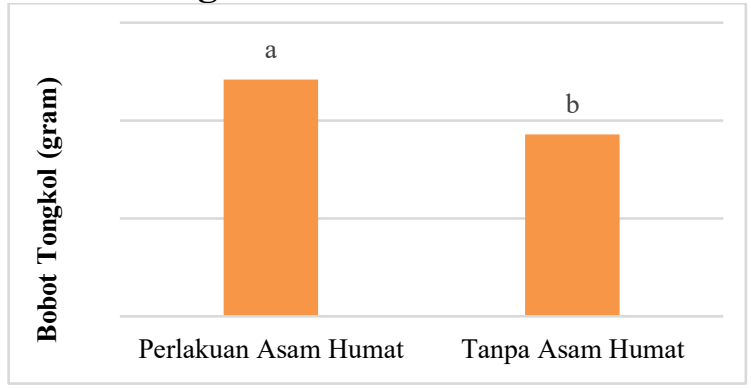

Gambar 5. Rata-rata bobot tongkol

Keterangan : Nilai rerata antar perlakuan yang diikuti dengan huruf sama pada pengamatan menunjukkan tidak berbeda nyata pada uji-t taraf $5 \%$.

Hasil $t$-test menunjukkan bahwa perlakuan asam humat berpengaruh nyata terhadap bobot tongkol. Peningkatan pertumbuhan tanaman jagung manis dengan ditanda meningkatnya luas daun dan bobot total tanaman akibat proses fotosintesis yang berjalan secara baik sehingga translokasi fotosintat ke bagian tongkol dapat optimal. Unsur hara kalium dan asam humat mempengaruhi dan dapat meningkatkan pertumbuhan dan hasil tanaman jagung manis, kalium memiliki peran sebagai pengatur air di dalam sel dan sebagai transfer kation yang melewati membran. Wibowo, dkk (2017) menjelaskan bahwa peningkatan bobot tongkol sangat dipengaruhi oleh aktivitas fotosintesis dan translokasi fotosintat kebagian tongkol. Apabila pertumbuhan tanaman terhambat, maka proses translokasi unsur hara dan fotosintat kebagian tongkol juga akan terhambat 
akibatnya, berat tongkol tanaman jagung akan ringan sehingga produksinya akan sedikit.

\section{Tingkat Kemanisan}

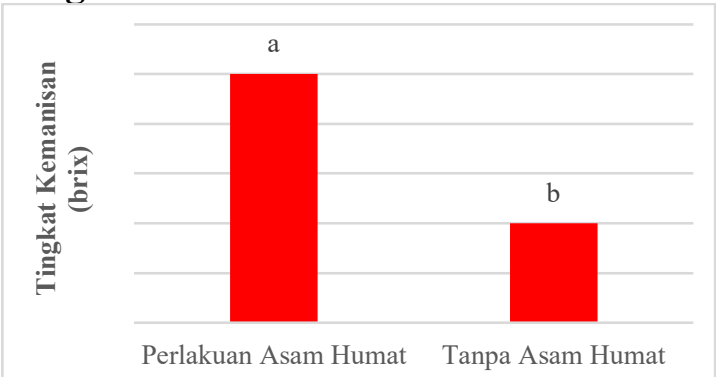

Gambar 6. Rata-rata tingkat kemanisan

Keterangan : Nilai rerata antar perlakuan yang diikuti dengan huruf sama pada pengamatan menunjukkan tidak berbeda nyata pada uji-t taraf $5 \%$.

Hasil penelitian pada parameter pengamatan tingkat kemanisan (brix) menunjukkan bahwa perlakuan asam humat berpengaruh nyata terhadap tingkat kemanisan. Hal ini disebabkan oleh unsur kalium yang berperan dalam pembentukan gula dan transportasi gula hasil fotosintesis hasil tanaman, selaras dengan pendapat Pradipta et al., (2014) menyatakan bahwa kalium di dalam tanaman berfungsi dalam proses pembentukan gula dan pati, translokasi gula, aktivitas enzim dan pergerakan stomata. Aplikasi asam humat dan pupuk $\mathrm{KCl}$ mampu menyediakan ketersediaan unsur hara kalium yang diperlukan oleh tanaman jagung manis dalam fase pertumbuhan dan perkembangan. Selaras dengan pendapat Wibowo, dkk (2017), aplikasi pupuk $\mathrm{KCl}$ dengan dosis $200 \mathrm{~kg} / \mathrm{ha}$ memberikan respon nyata terhadap kadar gula jagung manis. Sehingga semakin besar dosis kalium yang digunakan maka kadar gula pun semakin meningkat.

\section{Kelayakan Usahatani}

Tabel 1 Analisis Usahatani Budidaya Tanaman Jagung Manis per luasan $120 \mathrm{~m}^{2}$ per Satu kali musim Tanam

\begin{tabular}{|c|c|c|}
\hline Analisa Usaha Tani & $\begin{array}{c}\text { Proflukum Asum } \\
\text { Humat }\end{array}$ & Тара Аам Hunat \\
\hline Hail Iroding (kg) & $1 \mathrm{IS}$ & $1 \mathrm{li4}$ \\
\hline Bign Phodusi(Bp) & 6․․ำ & $571.2 \%$ \\
\hline Hamp Jual (Rokgl & $5 . \mathrm{H}$ & s.ดั \\
\hline Temaknan (Rp) & 925.MH & Bมดัด \\
\hline Kounlunga (Rp) & 292.831 & 248.730 \\
\hline RC Ratía & 1,46 & 1,43 \\
\hline BC Ratia & 0,46 & $0,4.4$ \\
\hline BEP Unit (kg) & 126,43 & 114,25 \\
\hline BEI Hasa (Rn) & 5.417 .13 & .38 .35 \\
\hline
\end{tabular}

Sumber: Analisis Data Primer (2019)

Pemasukan diperoleh dari jumlah seluruh jagung manis yang dihasilkan dikalikan dengan harga satuan pada saat penelitian. Produksi jagung manis dengan aplikasi asam humat adalah 185 kilogram, harga jual jagung manis pada saat penelitian adalah Rp. 5.000 per kilogram, maka nilai pemasukan usahatani jagung per luasan $120 \mathrm{~m}^{2}$ adalah Rp. 925.0000. Keuntungan adalah selisih antara penerimaan dengan biaya produksi total. Biaya produksi yang dikeluarkan sebesar Rp. 632.170 diperoleh penerimaan sebesar Rp. 925.000 sehingga keuntungan dari usahatani jagung manis dengan aplikasi asam humat sebesar Rp. 292.830.

Untuk mengetahui besarnya imbangan pemasukan dan biaya atau $\mathrm{R} / \mathrm{C}$ pada usahatani jagung manis dengan aplikasi asam humat dihitung dengan cara 
membandingkan antara rata-rata penerimaan dengan rata-rata biaya. Hasil analisis menunjukkan bahwa nilai $\mathrm{R} / \mathrm{C}$ usahatani jagung manis dengan aplikasi asam humat adalah 1,46 dengan perhitungan sebagai berikut:

$\mathrm{R} / \mathrm{C}=$ Pemasukan

$$
\begin{aligned}
& \text { Biaya produksi } \\
&= 925.000 \\
& \hline 632.170 \\
&= 1,46
\end{aligned}
$$

Nilai R/C sebesar 1,46 artinya dari setiap biaya yang dikeluarkan dalam budidaya tanaman jagung manis menggunakan asam humat sebesar Rp. 1 maka akan diperoleh pemasukan sebesar Rp. 1,46 dengan demikian keuntungan yang diperoleh sebesar 0,46.

\section{KESIMPULAN}

Berdasarkan hasil dan pembahasan, maka dapat diambil kesimpulan sebagai berikut:

1) Pemberian asam humat dengan dosis $20 \mathrm{~kg} / \mathrm{ha}$ memberikan pengaruh nyata terhadap pertumbuhan tinggi tanaman umur 28 HST, 35 HST, 42 HST, jumlah daun per tanaman umur 14 HST, 28 HST, 35 HST, dan 42 HST, diameter tongkol, bobot tongkol, panjang tongkol, tingkat kemanisan. Pemberian asam humat $20 \mathrm{~kg} / \mathrm{ha}$ memberikan bobot tongkol mencapai $185 \mathrm{~kg}$ per $120 \mathrm{~m}^{2}$ atau $15,42 \mathrm{ton} / \mathrm{Ha}$.

2) Besarnya $\mathrm{R} / \mathrm{C}$ yang diperoleh dalam budidaya tanaman jagung manis dengan aplikasi asam humat diperoleh sebesar 1,46 artinya setiap penambahan biaya (input) Rp. 1 akan menghasilkan pemasukan (output) sebesar 1,46. Dengan demikian maka usahatani jagung manis dengan aplikasi asam humat adalah menguntungkan.

\section{DAFTAR PUSTAKA}

Dani, U. (2018). Pengaruh Kombinasi Asam Humat, Jarak Tanam, dan Jumlah Bibit per Lubang Tanam
Terhadap Pertumbuhan dan Hasil Tanaman Padi (Oryza satiiva L. 'Pandan Puteri'). Jurnal Ilmu Pertanian dan Peternakan, 6(1), 89.

Ferrara, G., dan G. Brunetti. (2010). Effect of the times of aplication of a soil humic acid on berry quality of table grape (Vitis vinifera L.) cv Italia Spanish. J. Agric. Res, 8(3), 817822.

Firda, O. Mulyani, dan A. Yuniarti. (2016). Pembentukan, Karakteristik serta Manfaat Asam Humat Terhadap Adsorbsi Logam Berat (Review)., Jurnal Soilrens, 14(2), 9-13.

Hermanto. D, N.K.T Dharmayani, R. Kurnianingsih dan S.R. Kamali. (2013). Pengaruh Asam Humat sebagai Pelengkap Pupuk terhadap Ketersediaan dan Pengambilan Nutrien pada Tanaman Jagung di Lahan Kering Kec. Bayan-NTB, Jurnal Ilmu Pertanian, 16(2), 28-41.

Ihdaryanti, M.A. (2011). Pengaruh Asam Humat dan Cara Pemberiannya terhadap Pertumbuhan dan Produktivitas Tanaman Padi (Oryza sativa) (Skripsi).

Kementrian Pertanian Republik Indonesia. (2018). Statistik Pertanian. Jakarta: Pusat Data dan Sistem Informasi Pertanian Kementrian Pertanian Republik Indonesia.

Mutaqin, Z., H. Saputra, D. Ahyuni. (2019). Respon Pertumbuhan dan Produksi Jagung Manis terhadap Pemberian Pupuk Kalium dan Arang Sekam. Jurnal Planta Simbiosa, $1(1), 39-50$. 
Pettit, R.E. (2008). Organic Matter, Humus, Humate, Humic Acid, Fulvic Acid and Humin: Their Importance in Soil Fertility and Plant Health. Emeritus Associate Professor Texas A\&M University.

Pradipta, R., K.P. Wicaksono dan B. Guritno. (2014). Pengaruh Umur Panen dan Pemberian Berbagai Dosis Pupuk Kalium Terhadap Pertumbuhan dan Kualitas Jagung Manis (Zea mays saccharata Sturt.) Jurnal Produksi Tanaman, 2(7), 592599.

Sari, W. I., S. Fajriani, dan Sudiarso. (2016). Respon Pertumbuhan Tanaman Jagung Manis (Zea mays saccharata Sturt) Terhadap Penambahan Berbagai Dosis Pupuk Organik Vermikompos dan Pupuk Anorganik. Jurnal Produksi Tanaman, 4(1), 57-62.

Sirajuddin, M. dan S. A. Lasmini. (2010). Respon Pertumbuhan dan Hasil Jagung Manis (Zea mays saccharata) Pada Berbagai Waktu Pemberian Pupuk Nitrogen dan Ketebalan Mulsa Jerami. Jurnal Agroland, 17(3), 184-191.

Suwardi, E.M. Dewi, dan B.A. Hermawan. (2009). Aplikasi Zeolit sebagai Karier Asam Humat untuk Peningkatan Produksi Tanaman Pangan. Jurnal Zeolit Indonesia, 8(1), 44-51.

Syafruddin, Nurhayati, dan R. Wati. (2012). Pengaruh Jenis Pupuk Terhadap Pertumbuhan dan Hasil Beberapa Varietas Jagung Manis. Jurnal Floratek, 7, 107-114.

Tahir, M. M., M. Khurshid, M. Z. Khan, M. K. Abbasi and M. H. Kazmi. (2011).
Lignite-Derived Humic Acid Effect on Growth of Wheat Plants in Different Soils. Pedosphere. 21(1), 124-131.

Wibowo, A. S., N. Barunawati, M. D. Maghfoer. (2017). Respons Hasil Tanaman Jagung Manis (zea mays L. saccharata) Terhadap Pemberian $\mathrm{KCl}$ dan Pupuk Kotoran Ayam, Jurnal Produksi Tanaman, 5(8), 1381-1388. 